\title{
PENGGUNAAN MEDIA TAYANGAN TELEVISI "PADA ZAMAN DAHULU" UNTUK MENINGKATKAN KEMAMPUAN MENCERITAKAN KEMBALI ISI CERITA FABEL PADA SISWA KELAS VII B SMP NEGERI 3 MENGWI
}

\author{
Ida Ayu Gede Pramiari, I Wayan Wendra, Ni Made Rai Wisudariani \\ Pendidikan Bahasa dan Sastra Indonesia \\ Universitas Pendidikan Ganesha \\ Singaraja, Indonesia \\ e-mail: piagdpramiari@yahoo.com, wayan_wendra@yahoo.com , \\ rai.wisudariani85@gmail.com
}

\begin{abstract}
ABSTRAK
Penelitian Tindakan Kelas (PTK) ini bertujuan untuk mengetahui (1) langkah-langkah penggunaan media tayangan televisi "Pada Zaman Dahulu" untuk meningkatkan kemampuan menceritakan kembali isi cerita fabel, (2) hasil penggunaan media tayangan televisi "Pada Zaman Dahulu" untuk meningkatkan kemampuan menceritakan kembali isi cerita fabel, (3) respons siswa terhadap penggunaan media tayangan televisi "Pada Zaman Dahulu". Subjek dalam penelitian ini adalah guru bahasa Indonesia dan siswa kelas VII B SMP Negeri 3 Mengwi. Pengumpulan data penelitian ini menggunanakan metode (1) observasi, (2) tes, (3) angket, dan (4) wawancara. Data yang diperoleh dianalisis dengan menggunakan teknik deskriptif-kualitatif dan deskriptif-kuantitatif. Hasil penelitian ini menunjukkan bahwa (1) terdapat tiga langkah dalam pembelajaran menceritakan kembali isi cerita fabel yaitu pendahuluan, inti, dan penutup, (2) kemampuan siswa dalam menceritakan kembali isi cerita fabel meningkat dengan perolehan skor rata-rata refleksi awal yaitu 59,35 (kurang), menjadi 70,11 (cukup) pada siklus I dan menjadi 81,41 (baik) pada siklus II, dan (3) siswa memberikan respons sangat positif terhadap penggunaan media tayangan televisi "Pada Zaman Dahulu" untuk meningkatkan kemampuan siswa dalam menceritakan kembali isi cerita fabel dengan skor rata-rata respons siswa 30,88 (positif) pada siklus I menjadi 32,41 (sangat positif) pada siklus II.
\end{abstract}

Kata-kata Kunci : Tayangan Televisi, Menceritakan Cerita Fabel

\begin{abstract}
This classroom action research (PTK) aimed for investigating 1 ) the steps to use television program "Once Upon a Time" to improve re-telling fable's content's skill. 2) result of using television program "Once Upon a Time" to improve re-telling fable's content's skill. 3) student's response towards the use of use television program "Once Upon a Time". The subject of this study is the teacher of Bahasa Indonesia and students of class VII B in SMP N 3 Mengwi. Data collection in this research (1) observation, (2) test, (3) questionnaire, and (4) interview. The data were analyzed by using descriptive- qualitative and descriptive-quantitative techniques. The result showed that: 1) There are three steps of re-telling the content of the story such as opening, whilst-activity, and closing. 2) the student's skill in re-writing the story increased from 59.35 (low) in pre-reflection into 70,11 (satisfactory) in 1st cycle and 81.41 (good) in 2nd cycle. 3) the student's response towards the use television program "Once Upon a Time" to improve re-telling fable's content's skill was positive with the average score 30.08 in 1st cycle into 32.41 in 2nd cycle.
\end{abstract}

Keyword: Television Impressions, Telling Fable Stories 


\section{PENDAHULUAN}

Dalam dunia pendidikan, fungsi bahasa adalah sebagai alat komunikasi dalam proses belajar mengajar yang melibatkan interaksi guru dan siswa di lingkungan sekolah. Keraf (dalam Suandi, 2014:4) menyebutkan bahwa bahasa adalah alat komunikasi antara anggota masyarakat, berupa lambang bunyi suara yang dihasilkan oleh alat ucap manusia. Komunikasi tersebut dapat dilakukan dengan berbagai cara. Dalam garis besarnya dikenal dua cara berkomunikasi yaitu komunikasi verbal dan komunikasi nonverbal. Dalam komunikasi verbal menggunakan bahasa sebagai sarananya. Namun, dalam komunikasi nonverbal menggunakan sarana gerak-gerik, warna, gambar, bendera, dan bunyi bel. Di antara kedua jenis komunikasi itu, komunikasi verbal yang dianggap paling sempurna, efesien, dan efektif (Wendra, 2013:2). Dalam hal ini, dapat dikatakan bahwa bahasa verbal merupakan bahasa yang sering digunakan oleh masyarakat.

Bahasa verbal yang sering digunakan dalam bermasyarakat adalah ragam bahasa lisan karena lebih praktis dalam penggunaannya. Bahasa verbal tersebut memiliki dua ragam bahasa, yaitu ragam bahasa lisan dan ragam bahasa tulis. Ketika seseorang menggunakan bahasa verbal (ragam bahasa lisan) dalam berinteraksi dengan orang lain maka disebut dengan berbicara. Dalam pembelajaran Bahasa Indonesia, terdapat keterampilan berbahasa salah satunya yaitu berbicara. Berbicara berarti mengucapkan kata atau kalimat kepada seseorang atau sekelompok orang untuk mencapai suatu tujuan tertentu (memberikan informasi atau memberi motivasi) (Hendrikus,2009:14). Kemampuan berbicara sangat penting di kuasai oleh siswa. Berbicara merupakan bentuk komunikasi manusia yang paling mendasar yang membedakan manusia dengan mahluk lainnya sehingga berbicara telah menjadi kodrat dari setiap manusia.
Dalam pembelajaran, kemampuan berbicara siswa sangat memengaruhi keberhasilan belajar siswa. Siswa yang kurang dalam kemampuan berbicara akan mengalami kesulitan dalam mengikuti kegiatan pembelajaran untuk semua mata pelajaran khususnya bahasa Indonesia yang di dalamnya terdapat aspek mengomunikasikan (menceritakan kembali isi cerita). Siswa di tuntut terampil dalam berkomunikasi, terampil menyatakan pikiran, ide, gagasan, dan perasaan. Selain itu, siswa harus terampil dalam menangkap informasi-informasi yang didapat dan terampil dalam menyampiakan informasiinformasi yang diterimanya.

Pada kurikulum 2013, siswa dituntut memiliki kreativitas dan inovasi yang tinggi. Kurikulum 2013 lebih menekankan pada fenomena alam, sosial, seni dan budaya. Kemudian, siswa diharapkan memiliki kompetensi sikap, keterampilan, dan pengetahuan yang lebih produktif. Kurikulum merupakan "chip" yang berisi berbagai keinginan dan harapan dari suatu komunitas masyarakat tertentu untuk memperbaiki keadaan dirinya, saat ini dan pada masa yang akan datang (Yani, 2014:2). Kurikulum dapat diartikan sebagai pusat dari semua sistem penggerak komponen pendidikan atau sebagai kumpulan dari berbagai pengalaman yang akan dipelajari oleh siswa. Hal tersebut menunjukan kurikulum tidak dapat dipisahkan dengan proses pembelajaran di sekolah.

Dalam silabus kurikulum 2013, pembelajaran bahasa Indonesia kelas VII terdapat kompetensi dasar menceritakan kembali. Salah satunya, yaitu menceritakan kembali isi fabel (Harsiati \& dkk. 2016). Sesuai dengan kompotensi dasar tersebut, siswa diharapkan memiliki kemampuan berkomunikasi secara efektif dan efesien sesuai dengan etika yang berlaku serta melatih siswa terampil dalam berbicara (bercerita) dengan menuangkan ide dan gagasannya secara kreatif dan kritis. Bercerita merupakan bagian dalam 
keterampilan berbicara. Bercerita adalah aktivitas yang dilakukan seseorang untuk mengulas kembali apa yang pernah didengar, dibaca, maupun dilihat. Namun, pada kenyataanya siswa sangat sulit dalam belajar berbicara khususnya dalam hal menceritakan kembali isi cerita.

Kesulitan dalam pembelajaran berbicara (bercerita) yang dialami oleh siswa bukanlah sebuah fenomena baru. Hal ini juga terjadi di kelas VII B SMP Negeri 3 Mengwi. Hasil wawancara yang pernah dilakukan dengan salah satu guru bahasa Indonesia di sekolah tersebut mengatakan bahwa siswa masih sulit dalam aspek berbicara khususnya dalam hal menceritakan kembali isi cerita. Siswa masih terlihat kebingungan ketika akan menceritakan kembali salah satu cerita yang disajikan. Siswa terlihat kesulitan dalam memulai cerita yang akan diceritakan. Hal tersebut terjadi dikarenakan siswa masih menghafalkan teks yang diberikan oleh guru. Ketika siswa lupa dengan teks yang mereka hafalkan akan berpengaruh terhadap kelancaran siswa dalam bercerita. Kurangnya kelancaran siswa dalam bercerita akan memengaruhi teman-temannya yang pada saat itu sebagai pendengar/penonton. Penyampaian cerita yang kurang menarik tersebut akan membuat kondisi kelas menjadi gaduh dan membosankan bagi siswa.

Hal tersebut memengaruhi skor yang diperoleh siswa. Ibu $\mathrm{Ni}$ Nengah Suartini, S. Pd. mengatakan bahwa skor rata-rata dari 34 siswa dalam berbicara khususnya dalam menceritakan kembali isi cerita masih di bawah KKM yakni 59,35 sedangkan KKM mata pelajaran bahasa Indonesia 60. Namun, di SMP Negeri 3 Mengwi khusunya bahasa Indonesia terdapat pengatagorian penilaian yaitu 60 sampai 73 (cukup), 74 sampai 87 (baik), dan 88 sampai 100 (amat baik). Hal tersebut menandakan bahwa siswa belum mampu mencapai nilai dengan katagori baik yaitu 74 . Dari 34 siswa yang mencapai KKM hanya 8 orang dan yang mampu melampaui KKM hanya 7 orang. Jadi total siswa yang mampu mencapai KKM hanya 15 orang. Data tersebut menunjukan dari 34 siswa hanya $44,11 \%$ yang mampu meraih katagori cukup sedangkan sisanya $55,88 \%$ masih katagori kurang. Berdasarkan hal tersebut, dapat disimpulkan bahwa skor bercerita di kelas VII B SMP Negeri 3 Mengwi masih rendah.

Rendahnya kemampuan siswa dalam menceritakan kembali isi cerita tidak hanya didominasi oleh satu faktor saja, melainkan ada dua faktor yang memengaruhi yaitu faktor internal dan eksternal. Adapun faktor internalnya yaitu (1) siswa masih terlihat kurang percaya diri, (2) siswa menceritakan kembali isi cerita dengan melakukan teknik penghafalan sehingga dalam kelancaran penyampaian cerita masih kurang, (3) siswa merasa takut dalam penyampaian cerita, dikarenakan bahasa yang ia gunakan tidak sesuai dengan yang ia inginkan, (4) siswa merasakan jenuh jika diberikan media yang berupa teks karena minat baca siswa kurang sehinga siswa menjadi tidak memperhatikan pelajaran. Hal tersebut akan berpengaruh terhadap kejelasan isi cerita. Selain faktor internal, faktor eksternal pun memengaruhi cara bercerita siswa, yaitu penggunaan media pembelajaran. Penggunaan media pembelajaran diberbagai sekolah masih kurang dan belum merata khusunya di SMP Negeri 3 Mengwi. Padahal, media merupakan fasilitas penunjang dalam pembelajaran yang keberadaannya sangat penting. Penggunaan media akan lebih menjamin terjadinya pemahaman terhadap materi ajar dan retensi yang lebih baik terhadap isi pelajaran (Jalinus \& Ambiyar. 2016:21).

Media merupakan sesuatu yang bersifat meyakinkan pesan dan dapat merangsang pikiran, perasaan, dan kemauan audiens atau siswa sehingga dapat mendorong terjadinya proses belajar pada diri siswa tersebut (Wati, 2016:3). Namun, media yang sering digunakan oleh guru adalah media cetak (diktat, modul, handout, buku teks, poster, majalah, dan 
surat kabar). Guru jarang menggunakan media yang berbentuk audiovisual seperti tayangan televisi. Hal tersebut dikarenaakan kurangnya fasilitas yang tersedia di sekolah dan guru sulit mengaplikasikan atau mengunakan alat elektronik pada saat pembelajaran. Pemanfaatan media pembelajaran sangat erat dengan peningkatan kualitas pembelajaran yang diharapkan. Adanya media atau sarana dan prasana pembelajaran merupakan faktor pendukung dalam mengimplementasikan kurikulum. Selain itu, pemakaian media sangat strategis dalam pembelajaran karena dapat dijadikan instrumen akselerasi pencapaian tujuan kurikulum.

Adanya permasalahan tersebut, maka diperlukan sesuatu yang menarik untuk menunjang proses pembelajaran di dalam kelas sehingga siswa dapat melakukan pembelajaran dengan baik. Salah satu caranya, yaitu membuat media yang dekat dan menarik bagi siswa, sehingga proses pembelajaran menjadi lebih aktif, efektif, dan menyenangkan. Salah satu jenis media pembelajaran yang dapat digunakan dalam pembelajaran menceritakan kembali isi cerita fabel adalah tayangan televisi "Pada Zaman Dahulu". Banyak stasiun televisi menayangkan cerita fabel seperti, Tom and Jerry, Donald Bebek, Munki And Trunk, Timmy Time, Lava, dan My Little Pony. Namun, tayangan televisi "Pada Zaman Dahulu" yang ditayangkan di MNCT, merupakan tayangan yang paling tepat untuk di sampaikan kepada siswa.

Terdapat beberapa kelebihan dari penggunaan tayangan televisi tersebut sebagai media dalam pembelajaran antara lain: (1) dalam setiap episode selalu menggunkan alur yang sama (2) bahasa yang digunakan dalam tayangan televisi "Pada Zaman Dahulu" unik, yaitu menggunakan bahasa Melayu. Penggunaan bahasa tersebut akan menambah wawasan siswa mengenai bahasa Melayu. Hal itu dikarenakan bahasa Indonesia memiliki kemiripan dengan bahasa Melalu sehingga tidak menyulitkan siswa dalam memaknai alur dalam cerita tersebut. Selain itu, tayangan tersebut telah terdapat terjemahannya agar siswa lebih mudah dalam memahami cerita tersebut, (3) tayangan ini berisikan nasihat-nasihat yang mampu mengembangkan pendidikan karakter siswa. Hal tersebut dikarenakan alur ceritanya sangat dekat dengan keadaan siswa dalam kesehariannya, (4) tayangan ini mempunyai potensi yang sangat besar sebagai penetrasi dalam memengaruhi sikap seseorang, kreativitas, motivasi, dan inovasi siswa, (5) tayangan ini juga bersifat hiburan, dalam proses pembelajaran menjadi lebih santai dan mampu menarik perhatian siswa. Mengingat siswa SMP masih dalam proses peralihan dari SD ke SMP sangat tepat diberikan tayangan kartun/animasi dalam proses pembelajaran. $\mathrm{Hal}$ tersebut dikarenakan mental siswa masih dominan gemar dalam bermain. Freud memandang bermain sama seperti fantasi atau lamunan (Tedjasaputra, 2001:7). Oleh karena itu, bermain sangat penting diberikan untuk perkembangan emosi anak (siswa) dan psikologis siswa.

Tayangan Televisi "Pada Zaman Dahulu" merupakan film yang di dalamnya menggunakan teknik bercerita dengan menggabungkan dunia realita dan imajinasi. Tayangan ini memiliki beberapa episode dan dibagi menjadi empat sesi, di antaranya: (1) Sang Kancil Mengira Buaya (2) Sang Kancil \& Harimau, (3) Kura-Kura dan Monyet, (4) Semut, Merpati, dan Gajah, (5) Belalang dan Semut, (6) Kura-Kura \& Itik, dan (7) Kera Sumbang Yang Belagak Banyaknya tayangan yang tersedia, peneliti akan menggunakan episode Kera Sumbang yang Belagak. Dipilinnya tayangan ini dikarenakan memiliki karakteristik yang dekat dengan siswa. Adanya kegiatan bermain game dan perayaan ulang tahun akan membuat siswa merasa berada pada dunianya sendiri. Selain itu, adanya pendidikan karakter yang juga dekat dengan siswa seperti peduli lingkungan, peduli sosial, dan bersikap jujur. 
Penggunaan media tayangan televisi ini, akan dilakukan dengan cara mengunduh videonya dari internet dan menampilkannya di kelas melalui LCD/Proyektor. Tayangan ini diunduh pada situs https://www.youtube.com/watch?v=W5OgR $18 \mathrm{KCfC}$.

Penggunaan tayangan televisi yang bersifat audiovisual ini akan dapat memudahkan siswa dalam menceritakan kembali isi cerita fabel. Selain itu, televisi dalam program pendidikan merupakan medium yang baik dikarenakan peserta didik dapat memperoleh informasi-informasi yang auntentik (Jalinus \& Ambiyar. 2016). Hal tersebut dikarenakan siswa mampu melihat dan mendengarkan dari tayangan tersebut. Oleh karena itu, penggunaan media tayangan televisi (audiovisual) sebagai media penyampaian materi akan menjadi lebih efektif, kreatif dan inovatif. Sesuai uraian di atas, dapat disimpulkan bahwa dengan digunakannya tayangan televisi "Pada Zaman Dahulu" dalam pembelajaran akan dapat meningkatkan kemampuan siswa dalam menceritakan kembali isi cerita fabel.

Penelitian mengenai keterampilan berbicara (bercerita) pernah dilakukan oleh Indriani (2013), yaitu "Peningkatan Keterampilan Menceritakan Kembali Cerita Anak melalui Teknik Demontrasi dengan Media Boneka Upin dan Upin Siswa Kelas VII-B SMP Hutuhiyyah Mranggen Kabupaten Demak". Selain itu, penelitian tentang keterampilan berbicara (bercerita) juga pernah dilakukan oleh Januria (2014), yaitu "Meningkatkan Keterampilan Berbicara (Bercerita) Melalui Penerapan Teknik Menyelesaikan Cerita Siswa Kelas VII J SMP Negeri 2 Ubud Gianyar ". Selain kedua penelitian tersebut, terdapat penelitian sejenis lainnya, yaitu penelitian yang dilakukan oleh Ismayanti (2017), yaitu "Penggunaan Media Shadow Puppet untuk Meningkatkan Keterampilan Bercerita Siswa Kelas VII B SMP Negeri 2 Seririt".

Penelitian di atas memang sejenis dengan penelitian yang akan dilakukan peneliti. Namun, penelitian tersebut memiliki perbedaan dengan penelitian yang akan dilakukan saat ini. Perbedaannya terlihat pada penggunaan media yang digunakan ketika pembelajaran berlangsung. Penggunaan media tayangan televisi akan membantu siswa terfokus dalam memahami alur cerita fabel untuk diceritakan kembali. Selain itu, media ini termasuk baru dan belum pernah diterapkan pada siswa kelas VII SMP Negeri 3 Mengwi. Perbedaan lainnya terdapat pada subjek penelitian dan tempat penelitian. Subjek yang digunakan dalam penelitian ini adalah guru bahasa Indonesia dan siswa kelas VII B SMP Negeri 3 Mengwi sedangkan tempat penelitian ini berlokasi di SMP Negeri 3 Mengwi kabupaten Badung.

Dipilihnya SMP Negeri 3 Mengwi sebagai tempat penelitian karena di samping nilai berbicara khusunya dalam hal menceritakan kembali isi cerita siswa masih rendah dan selain itu SMP Negeri 3 Mengwi belum pernah menerapkan penggunaan media tayangan televisi dalam pembelajaran menceritakan kembali isi cerita sehinga dapat dikatakan bahwa penelitian ini baru dan sangat tepat untuk dikaji. Atas dasar pertimbangan tersebut, peneliti tertarik dalam melakukan penelitian ini dan mengangkat penelitian ini dengan judul "Penggunaan Media Tayangan Televisi "Pada Zaman Dahulu" untuk Meningkatkan Kemampuan Menceritakan Kembali Isi Cerita Fabel Pada Siswa Kelas VII B SMP Negeri 3 Mengwi”.

Ada pun rumusan masalah yang diangkat dalam penelitian ini yaitu (1) bagaimanakah langkah-langkah penggunaan media tayangan televisi "Pada Zaman Dahulu" untuk meningkatkan kemampuan menceritakan kembali isi cerita fabel pada siswa kelas VII B SMP Negeri 3 Mengwi ? (2) bagaimanakah hasil penggunaan media tayangan televisi "Pada Zaman Dahulu" untuk meningkatkan kemampuan menceritakan kembali isi cerita fabel pada siswa kelas VII B SMP Negeri 3 Mengwi ? (3) bagaimanakah respons siswa terhadap penggunaan media tayangan 
televisi "Pada Zaman Dahulu" untuk meningkatkan kemampuan menceritakan kembali isi cerita fabel pada siswa kelas VII B SMP Negeri 3 Mengwi?.

Hasil dari penelitian ini diharapkan mampu memberikan maanfaat bagi beberapa pihak, baik secara teoretis maupun praktis. Pertama, secara teoretis penelitian ini dapat bermanfaat sebagai pengembangan khazanah keilmuan dalam pengembangan jenis-jenis media pembelajara. Kedua, secara praktis penelitian ini dapat memberikan maanfaat bagi beberapa pihak antara lain sebagai berikut: (1) bagi Guru Bahasa Indonesia, hasil penelitian ini dapat digunakan sebagai salah satu referensi dalam pemilihan atau penggunaan media pembelajaran menceritakan kembali isi certa fabel, (2) bagi Siswa, hasil penelitian ini dapat meningkatkan kemampuan siswa dalam menceritakan kembali isi cerita fabel dan memudahkan siswa dalam menceritakan kembali isi cerita fabel, (3) bagi Mahasiswa Calon Guru dapat menggunakan penelitian ini sebagai salah satu dasar pemahaman dalam memilih media pembelajaran menceritakan kembali isi cerita fabel, (4) bagi Kepala Sekolah, hasil penelitian ini dapat menjadi pedoman dalam merencanakan kegiatan workshop yang berkaitan dengan penggunaan media pembelajaran di sekolah, dan (5) bagi Peneliti Lain, hasil penelitian ini dapat bermanfaat sebagai salah satu referensi dalam melaksanakan penelitian sejenis.

\section{METODE PENELITIAN}

Dalam sebuah penelitian diperlukan metode untuk menuntun peneliti dalam melakukan penelitian. Hal tersebut dikarenakan metode penelitian banyak mengulas mengenai cara dalam pelaksanaan penelitian. Penelitian ini menggunakan rancangan penelitian tindakakan kelas. Melalui penelitian tindakan kelas, masalah-masalah pendidikan dan pembelajaran dapat dikaji, ditingkatkan, dan dituntaskan sehingga proses pendidikan dan pembelajaran yang inovatif dapat diwujudkan secara sistematis dan hasil belajar siswa menjadi lebih optimal. Pelaksanaan penelitian tindakan kelas atau PTK dilakukan secara bertahap dan multisiklus. Setiap siklus terdiri atas refleksi awal, rencana tindakan, pelaksanaan tindakan, observasi/ evaluasi, dan refleksi. Subjek dalam peneliitian ini yaitu guru bahasa Indonesia dan siswa kelas VII B SMP Negeri 3 Mengwi. Objek dalam penelitian ini adalah langkah-langkah penggunaan media tayangan televisi "Pada Zaman Dahulu", kemampuan hasil belajar siswa dalam menceritakan kembali isi cerita fabel dan respons siswa terhadap pengunaan media tayangan televisi "Pada Zaman Dahulu".

Adapun metode pengumpulan data yang digunakan dalam penelitian ini yaitu metode observasi, metode tes, angket, dan wawancara. Metode observasi digunakan untuk mengetahui penggunaan media tayangan televisi "Pada Zaman Dahulu" dalam pembelajaran di kelas. Metode tes digunakan untuk mengetahui kemampuan siswa dalam menceritakan kembali isi cerita fabel. Metode angket digunakan untuk mengetahui respons siswa terhadap penggunaan media tayangan televisi "Pada Zaman Dahulu" dalam meningkatkan kemampuan siswa menceritakan kembali isi cerita fabel. Metode wawancara digunakan untuk mengetahui informasi mengenai aktivitas guru dan siswa yang tidak dapat terungkap melalui lembar observasi. Selain itu, metode wawancara digunakan untuk mengetahui masalah atau kendala yang dihadapi oleh guru dan siswa saat melaksanakan pembelajaran.

Penelitian ini menggunakan instrumen sebagai alat untuk mendukung penggunaan metode tersebut. Instrumen yang digunakan dalam penelitian ini adalah lembar observasi aktivitas belajar-mengajar dan lembar angket respons siswa.Teknik analisis data yang digunakan yaitu deskriptif kualitatif dan deskriptif kuantitatif. Teknik analisis deskriptif kuantitatif merupakan teknik analisis yang digunakan untuk menganalisis data berupa angka- 
angka sedangkan teknik analisis deskriptif kualitatif merupakan teknik analisis yang digunakan untuk menganalisis data dengan cara menginterpretasikan data yang diperoleh dengan menggunakan kata-kata.

Adapun kriteria keberhasilan yang digunakan sebagai patokan dalam mengakhiri penelitian ini adalah sebagai berikut. Pertama, kriteria keberhasilan hasil belajar kemampuan menceritakan kembali isi cerita siswa ditunjukkan dengan adanya keberhasilan pemerolehan skor rata-rata kelas pada kategori baik atau $75 \%$ dari jumlah keseluruhan siswa memeroleh nilai kategori baik. Kedua, kriteria respons siswa ditunjukkan oleh perolehan persentase $80 \%$ dari jumlah keseluruhan siswa merespons positif atau senang terhadap tindakan pembelajaran.

\section{HASIL DAN PEMBAHASAN}

Dari uraian hasil penelitian di atas, terdapat beberapa temuan yang dipandang peting sehubungan dengan peningkatan kemampuan menceritakan kembali isi cerita fabel pada siswa. Adapun temuan penting yang ditemukan antara lain: (1) langkahlangkah penggunaan media tayangan televisi "Pada Zaman Dahulu" yang dapat meningkatkan kemampuan menceritakan kembali isi cerita fabel, (2) peningkatan kemampuan siswa dalam menceritakan kembali isi cerita fabel dengan menggunakan media tayangan televisi "Pada Zaman Dahulu", dan (3) siswa memberikan respons sangat setuju terhadap penggunaan media tayangan televisi "Pada Zaman Dahulu".

Temuan pertama, menemukan langkah-langkah pembelajaran menceritakan kembali isi cerita fabel dengan penggunaan media tayangan televisi "Pada Zaman Dahulu" dan langkahlangkah yang berkonstribusi terhadap peningkatan hasil kemampuan siswa dalam menceritakan kembali isi cerita fabel. Secara umum, langkah-langkah pembelajaran ini dibagi menjadi tiga bagian yakni pendahuluan, inti, dan penutup. Dalam langkah-langkah pembelajaran ini, terdapat beberapa kegiatan pembelajaran yang menjadi titik penekanan agar kemampuan siswa dalam menceritakan kembali isi cerita fabel dapat meningkat. Adapun kegiatan tersebut adalah (1) pemberian permainan kecil di awal pembelajaran, (2) pemberian contoh penyampaian bercerita oleh guru, (3) pemilihan cerita yang lebih sederhana, dan (4) pemberian motivasi, (5) penekanan pada aspek penilaian, (6) pemberian diskusi, (7) membentuk keadaan kelas yang lebih kondusif.

Pemberian permainan kecil diberikan pada awal kegiatan. Permainan kecil dalam pembelajaran dirasa perlu untuk membuat siswa lebih senang dan semangat dalam mengikuti pembelajaran. Permainan ini dipadukan dengan materi perlajaran sehingga tidak banyak waktu yang diperlukan. Bermain merupakan jembatan bagi anak secara informal menjadi formal. Dalam hal ini, guru harus mampu mengondisikan keadaan siswa di dalam kelas. Pernyataan tersebut diperkuat oleh Fitrianti (2016) yang mengatakan bahwa guru harus dapat membuat suatu pengajaran menjadi lebih efektif juga menarik dan bernilai guna sehingga bahan pelajaran yang disampaikan akan membuat siswa merasa senang dan merasa perlu untuk mempelajarinya. Oleh karena itu, seorang guru harus mampu berfikir kritis sehingga menghasilkan kreatifitas yang akan memunculkan sebuah inovasi dalam pembelajaran, salah satu contohnya yaitu dengan memberikan permainan kepada siswa pada saat pembelajaran.

Permainan ini sekaligus digunakan oleh guru untuk menyampaikan pelajaran yang telah diajarkan sebelumnya. Dalam permainan ini, seluruh siswa berdiri dan melakukan tepuk pingpong. Guru akan memantau siswa yang tidak bersemangat dalam permainan tersebut. Jika pada saat tepukan terakhir masih terdapat siswa yang lemas dan lesu akan diberikan sebuah pertanyaan oleh guru. Pertanyaan inilah yang berkaitan dengan pelajaran sebelumnnya. Secara tidak langsung, 
dalam permainan ini akan mengarahkan siswa untuk mengingat pelajaran sebelumnya. Peran kreatif dan inovasi seorang guru sangat diperlukan dalam pembelajaran agar menjadi lebih baik.

Selain diberikannya sebuah permainan, dalam pembelajaran guru juga memberikan contoh kepada siswa mengenai cara bercerita. Hal ini sangat perlu diberikan kepada siswa sehingga siswa lebih memahami cara bercerita yang baik dan benar. Melalui pemberian contoh siswa akan lebih terinspirasi untuk mengeluarkan idea tau gagasan mereka dalam bercerita. Hal tersebut sesuai dengan pendapat Suyanto \& Asep (2013) pekerjaan guru adalah terus menginspirasi siswa agar kreativitas mereka selalu berkembang. Dalam hal ini, pemberian contoh oleh guru akan memengaruhi hasil kemampuan siswa dalam pembelajaran. Guru memberikan contoh bercerita den Siswa akan lebih terbantu ketika diberikan contoh langsung oleh seorang guru.

Berdasarkan hasil wawancara, banyak siswa yang mengeluhkan bahwa tayangan yang digunakan terlalu banyak tokoh ceritanya sehingga sulit untuk mengingatnya. Selain itu, pada siklus I siswa terlihat sulit dalam mengingat alur dan tokoh yang terdapat pada tayangan tersebut sehingga pada siklus II lebih ditekankan penggunaan tayangan yang lebih sederhana dan tidak mengurangi makna dari cerita fabel. Adanya permasalah pada siklus I, membuat peneliti dan guru merancang penggunaan media yang lebih sederhana. Pemilihan tayangan yang lebih sederhana dengan tokoh yang lebih sedikit tentunya menjadi alternativ terbaik agar membuat siswa lebih mudah dalam bercerita.

Dalam hal ini guru haruslah pandai dalam memilih media yang sesuai dan cocok digunakan untuk mencapai tujuan pengajaran yang telah ditetapkan. Media yang baik adalah media yang menarik dan mampu memberikan informasi kepada siswa. Hal tersebut diperkuat oleh pendapat Kustiawan (2016:6) media diartikan sebagai alat komunikasi yang digunakan dalam proses pembelajaran untuk membawa informasi berupa materi ajar dari guru kepada murid sehingga murid lebih tertarik untuk mengikuti kegiatan pembelajaran. Adapun media yang dipilih pada siklus II yaitu penggunaan media tayangan televivi Pada Zaman Dahulu "Serigala Yang Nakal". Tayangan tersebut lebih sederhana daripada tayangan sebelumnya. Dalam tayangan ini hanya terdapat empat tokoh binatang yaitu, Serigala, Burung, Tupai, dan Kancil. Pemilihan media yang tepat sangat penting dilakukan agar sesuai dengan kemampuan siswa.

Hal lainnya yaitu pemberian motivasi oleh guru kepada siswa juga sangat penting dilakukan dalam pembelajaran. Menutut Trabani, (dalam Darmadi, 2017:269) pentingnya motivasi belajar siswa atau motivasi dalam belajar, yaitu bahwa belajar harus diberi motivasi dengan berbagai cara sehingga minat yang dipentingkan dalam belajar itu dibagun dari minat yang telah ada pada diri anak. Hal tersebut menandakan bahwa tanpa adanya motivasi dalam pembelajaran makan tujuan pembelajaran sulit tercapai. Salah satu cara pemberian motivasi yang sederhana yaitu dengan cara memberikan pujian kepada siswa atau dengan memerhatikan gerakgerik siswa. Ketika guru telah memberikan perhatiannya kepada siswa, maka siswa pasti akan merasa lebih termotivasi dalam mengikuti kegiatan pembelajaran. Selain itu, pada saat tanya jawab guru sebaiknya memberikan pujian melalui kata-kata yang baik kepada siswa seperti, bagus, benar, baik sekali, berikan tepuk tangan, dls. Hal tersebut dilakukan agar siswa lebih tenang dan nyaman dalam mengikuti pelajaran.

Selain motivasi yang berkonstribusi dalam peningkatan hasil pembelajaran siswa, terdapat juga pemberian penekanan terhadap aspek penilaian dalam pembelajaran. Guru memberikan penekanan terhadap aspek-aspek penilaian yang masih rendah khususnya dalam penyampaian intonasi dan kejelasan lafal siswa pada saat bercerita. Kurangnya 
kejelasan lafal dan intonasi pada siklus I, membuat guru lebih menekankan mengenai hal tersebut pada siklus II. Guru memberikan penegasan, dalam bercerita harus memiliki suara yang keras sehingga jelas terdengan oleh teman satu kelas. Dengan suara yang keras, siswa harus mampu menyampaikan intonasi dan kejelasan lafal yang tepat. Hal tersebut akan menandakan bahwa siswa lebih percaya diri dalam penyampaian ceritanya.

Berikutnya yaitu pemberian diskusi.

Sebelum siswa bercerita, siswa diberikan waktu untuk mendiskusikan mengenai alur dan isi dari cerita yang telah ditayangkan. $\mathrm{Hal}$ ini dilakukan untuk memperkuat gagasan ataupun ide siswa pada saat bercerita. Siswa akan lebih memahami alur cerita yang ditayangkan sehingga dalam bercerita lebih mudah dan lancar. Tidak hanya itu, kegiatan diskusi ini akan membuat siswa lebih percaya diri dalam bercerita dan memantapkan siswa dalam bercerita. Hal tersebut dikarenakan guru memberikan kesempatan diskusi untuk membahasa mengani unsur-unsur dalam cerita yang telah ditayangkan guna menyamakan pendapat sehingga terjadi persepsi yang sama pada saat bercerita.

Terakhir yaitu guru membentuk keadaan kelas yang lebih kondusif. Guru harus mampu mengontrol situasi di dalam kelas maupun di luar kelas. Menurut Jennings dan Greenberg (dalam Baedowi,dkk.2015:277) guru yang memiliki kompetensi kepribadian dan sosial yang baik akan mampu membentuk suasana kelas yang kondusif melalui kemampuannya dalam membagun hubungan dengan murid. Dalam hal ini guru dituntut harus memiliki kedekatan dengan siswa sehingga mampu membentuk kelas menjadi lebih kondusif. Pada saat pelaksanaan siklus II, guru telah melakukan tindakan pendekatan dengan siswa seperti guru telah memberikan sebuah motivasi, memilihkan media yang lebih sederhana agar sesuai dengan kemampuan siswa, dan memberikan contoh cara bercerita sehingga siswa merasa lebih dekat dengan guru. Dari paparan di atas, itulah beberapa langkah-langkah yang harus ada dalam pembelajaran menceritakan kembali isi cerita fabel.

Temuan kedua, penggunaan media tayangan televisi "Pada Zaman Dahulu" dapat membantu meningkatkan kemampuan menceritakan kembali isi cerita fabel pada siswa kelas VII B SMP Negeri 3 Mengwi. Hal tersebut terbukti dengan adanya peningkatan hasil belajar siswa dari sebelum diberikan tindakan, siklus I dan siklus II. Hasil belajar tersebut dapat dilihat melalui diagram di bawah ini.

Diagram 1. Perbandingan antara skor ratarata kelas sebelum dilakukan tindakan, siklus I,dan siklus II

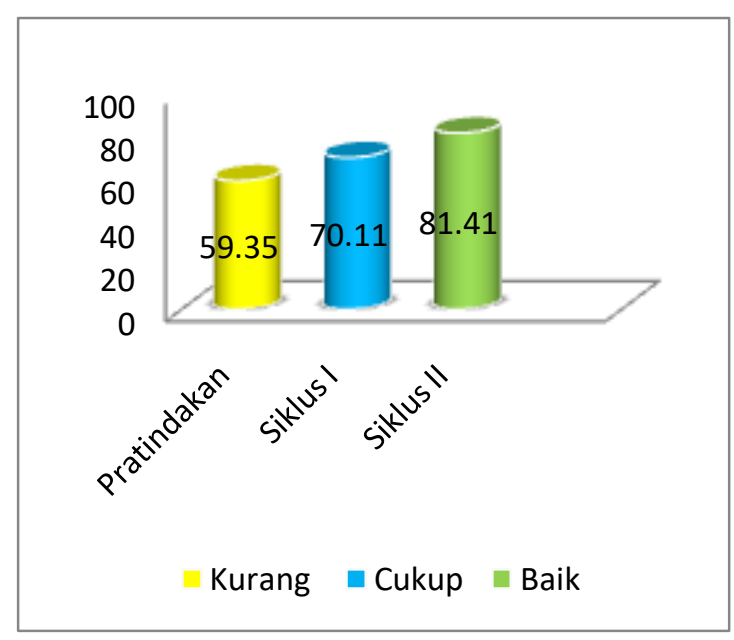

Pada siklus I nilai rata-rata siswa sebesar 70,11 (cukup) sedangkan pada siklus II sebesar 81,41 (baik). Peningkatan skor tersebut, dipengaruhi oleh penggunaan media tayangan televisi dalam pembelajaran yang dapat memberikan kesempatan langsung kepada siswa untuk melihat, mendengar, dan merasakan sebuah cerita. Cerita bukan hanya sekadar hiburan, melainkan dalam cerita terdapat sebuah amanat yang harus dipetik. Pernyataan tersebut senada dengan pendapat Simanjuntak (2008:6), cerita bukan sekadar untuk mengisi waktu, atau sebagai hiburan, melainkan sarana untuk menyampaikan suatu pesan atau ajaran. 
Penggunaan media tayangan televisi ini menjadikan siswa tidak bosan dalam mengikuti pembelajaran dan siswa dengan mudah mengetahui amanat yang terkandung dalam sebuah cerita.. Selain itu, menurut Day dan Back (dalam Prastowo, 2014:342) mengatakan bahwa penyajian yang menggunakan audio dan visual memberikan pengetahuan yang lebih daripada jika hanya menggunakan salah satu dari indra tersebut.

Temuan selanjutnya mengacu pada hasil angket, baik pada siklus I dan II menunjukan bahwa siswa merasa lebih senang pada saat pembelajaran dengan digunakannya media tayangan televisi "Pada Zaman Dahulu". Rasa senang dan semangat siswa tersebut dapat dilihat dari nilai rata-rata respons siswa yang diberikan oleh siswa dalam pembelajaran ini. Sebagian besar siswa memberikan respons positif terhadap tindakan yang dilakukan dalam pembelajaran. Hasil respons siswa mengalami peningkatan dari siklus I ke siklus II. Adapun peningkatan hasil tersebut dapat dilihat dari diagram di bawah ini.

Diagram 2. Perbandingan antara skor ratarata respons siswa siklus I, dan siklus II

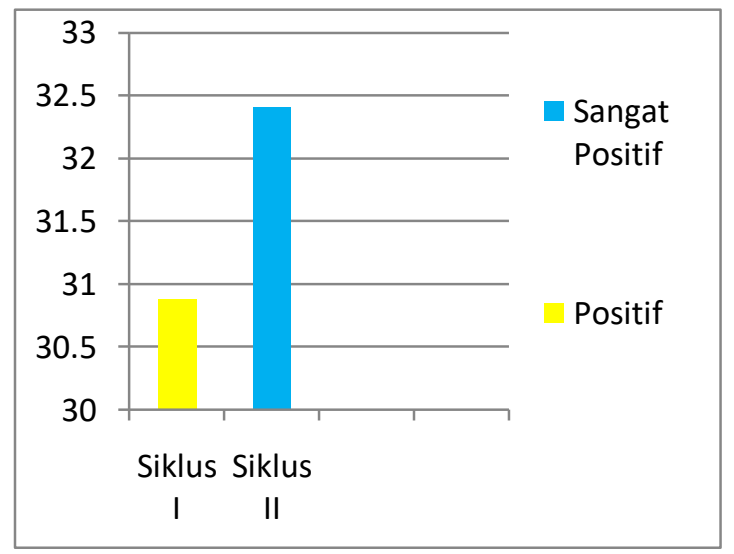

Pada siklus I skor rata-rata respons siswa adalah 30.88 (setuju) kemudian skor rata-rata siswa meningkat menjadi 32.41 (sangat setuju) pada siklus II. Temuan hasil penelitian ini sejalan dengan temuan penelitian sebelumnya yaitu penelitian oleh Made Novi Ismayanti Jurusan Pendidikan Bahasa dan Sastra Indonesia, Universitas
Pendidikan Ganesha pada tahun 2017. Penelitian ini berjudul "Penggunaan Media Shadow Puppet untuk Meningkatkan Keterampilan Bercerita Siswa Kelas VII B SMP Negeri 2 Seririt". Penelitian tersebut, memiliki persamaan dalam pemerolehan hasil, yakni adanya peningkatan rata-rata nilai pembelajaran. Hal tersebut juga terjadi pada penelitian ini, hasil yang diperoleh dalam penelitian ini mengalami peningkatan. Selain itu, penelitian ini samasama meningkatkan aspek bercerita dengan sebuah media. Pada penelitian Novi digunakan media yang berbentuk visual sedangkan pada penelitan ini digunakan media yang bersifat audiovisual. Kemudian, penelitian ini juga dapat memperbanyak khasanah tentang pembelajaran menceritakan kembali isi cerita fabel.

Dalam penelitian ini masih terbatas hanya mengkaji permasalahan mengenai menceritakan kembali isi cerita fabel dengan penggunaan media tayangan televisi "Pada Zaman Dahulu". Penggunaan media tayangan televisi tidak hanya dapat digunakan dalam aspek berbicara. Dalam aspek menulis pun dapat digunakan tayangan televisi sebagai media pembelajaran. Sebenarnya menulis pada dasarnya sama dengan bercerita yaitu hanya mengeluarkan ujaran-ujaran dari pemikiran seseorang (Nasanti, 2012). Berbicara dengan menulis memiliki persamaan yaitu sama-sama keterampilan bahasa yang bersifat produktif. Bersifat produktif artinya penulis dan pembicara berperan sebagai penyampai atau pengirim pesan kepada pihak lain (pendengar dan pembaca). Orang yang berbicara atau menulis akan mengeluarkan gagasan atau idenya untuk penyamaian sebuah informasi. Maka dari itu, penggunaan media tayangan televisi juga tepat digunakan untuk media menulis cerita naratif khususnya cerita fabel.

\section{SIMPULAN DAN SARAN}

Terdapat beberapa hal yang menjadi simpulan dalam penelitian ini. 
Pertama, langkah-langkah yang ditempuh dalam penggunaan media tayangan televisi "Pada Zaman Dahulu" untuk meningkatkan kemampuan menceritakan kembali isi cerita fabel yaitu: (1) guru membuka pelajaran dengan memberi salam dan mengecek kehadiran siswa, (2) guru meminta siswa untuk berdoa, (3) guru mengecek kelengkapan alat belajar siswa seperti buku pelajaran, buku catatan, buku tugas dan pulpen (4) guru mengkondisikan lingkungan belajar siswa (5) guru memberikan permainan agar siswa menjadi lebih semangat dalam mengikuti pembelajaran dan guru mengkaitkan dengan pembelajaran sebelumnya sehingga mampu mengefisienkan waktu (6) guru menyampaikan apersepsi terkait dengan materi pelajaran dengan pemberian contoh kepada siswa, (7) guru menyampaikan kompetensi dasar dan tujuan pembelajaran yang ingin dicapai, (8) guru membentuk kelompok 5-6 orang dalam satu kelompok dan ditentukan secara acak, (9) guru menjelaskan penggunaan media tayangan televisi "Pada Zaman Dahulu" sesuai dengan pendekatan saintifik, (10) guru menayangkan media tayangan televisi "Pada Zaman Dahulu" yang lebih sederhana sesuai dengan tingkat kemampuan siswa, (11) guru meminta siswa berdiskusi untuk menemukan unsurunsur dan alur cerita fabel yang telah ditayangkan sehingga siswa lebih percaya diri dalam bercerita, (12) guru memberikan kesempatan kepada siswa untuk bertanya sehingga dalam penyampain cerita siswa tidak terlihat kebingungan, (13) guru meminta siswa untuk praktik menceritakan kembali isi cerita fabel yang telah ditayangkan secara berkelompok, (14) guru memberikan penghargaan atau apresiasi kepada kelompok yang tampil di depan kelas agar siswa merasa tidak takut dalam bercerita, (15) guru meminta siswa (yang tidak tampil) untuk memberikan komentar dengan menuliskan disebuah kertas yang telah diberikan oleh guru sebelum setiap kelompok bercerita, (16) guru merangkum dan menyimpulkan materi pembelajaran disertai dengan penguatan dan penegasan simpulan yang telah dibuat oleh siswa, (17) guru memberikan tugas kepada siswa sebagai tindak lanjut, dan (18) guru mengakhiri pelajaran dengan berdoa dan mengucapkan salam kembali.

Kedua, penggunaan media tayangan televisi "Pada Zaman Dahulu" dapat meningkatkan kemampuan siswa dalam menceritakan kembali isi cerita fabel. Skor rata-rata yang dicapai siswa sebelum diberikan tindakan sebesar 59,35 (kurang) tetapi setelah diberikan tindakan pada siklus I skor rata-rata siswa menjadi 70,11 (cukup), dan skor rata-rata siswa pada siklus II menjadi 81,41 (baik). Persentase peningkatan nilai rata-rata siswa sebelum diberikan tindakan dan setelah diberikan tindakan pada siklus I, meningkat sebanyak $10,76 \%$ dan dari tindakan siklus I ke siklus II meningkat sebanyak 11,3\%. Dalam penelitian ini, tindakan pada siklus II sebagai tindakan yang terbaik karena 91,17 $\%$ siswa telah memenuhi nilai dengan katagori baik atau di atas nilai 74 .

Ketiga, respons siswa kelas VII B SMP Negeri 3 Mengwi terhadap penggunaan media tayangan televisi "Pada Zaman Dahulu" untuk meningkatkan kemampuan menceritakan kembali isi cerita fabel ialah sangat positif. Hal itu ditunjukkan dari nilai rata-rata respons siswa pada siklus I sebesar 30,88 yang tergolong pada kategori positif dan pada siklus II nilai rata-rata respons siswa meningkat sebesar 32,41 (sangat positif). Terjadi peningkatan sebesar 1,53\%. Dari respons yang diberikan, siswa merasa senang dengan penggunaan media yang digunakan dalam pembelajaran menceritakan kembali isi cerita.

Berdasarkan temuan-temuan dalam penelitian ini, peneliti dapat menyampaikan beberapa saran sebagai berikut (1) bagi guru bidang studi bahasa Indonesia, peneliti menyarankan agar menggunakan media tayangan televisi "Pada Zaman Dahulu" dalam pembelajaran menceritakan kembali isi cerita fabel. Selain itu, sebaiknya penggunaan media ini 
dikembangkan dalam pembelajaran agar menjadi lebih menarik, (2) bagi sekolah, peneliti menyarankan untuk menggunakan media tayangan televisi pada pembelajaran menceritakan kembali isi cerita guna meningkatkan kemampuan siswa dalam bercerita. Menunjang penggunaan media tersebut, peneliti juga menyarankan agar sarana dan prasarana sekolah lebih dioptimalkan, dan (3) bagi peneliti lain, penelitian ini masih terbatas pada aspek menceritakan kembali isi cerita fabel dengan penggunaan media tayangan televisi. Hendaknya peneliti lain dapat menerapkan media tersebut pada kegiatan menulis cerita naratif.

\section{DAFTAR PUSTAKA}

Baedowi, Ahmad \& dkk. 2017. Potret Pendidikan Kita. Tanggerang Selatan: PT Pustaka Alvabert.

Fitrianti, 2016. Sukses Profesi Guru dengan Penelitian Tindakan Kelas. Yogyakarta: Deepublish.

Harsiati, Titik \& dkk. 2016. Bahasa Indonesia. Jakarta: Kementrian Pendidikan dan Kebudayaan.

Hendrikus, Dori Wuwur. 2009. Retorika. Yogyakarta: Kanisius.

Indriani, Andrianita Widiastuti. 2013. Peningkatan Keterampilan Menceritakan Kembali Cerita Anak melalui Tehnik Demontrasi dengan Media Boneka Upin dan Upin Siswa Kelas VII-B SMP Hutuhiyyah Mranggen Kabupaten Demak. Skripsi (tidak diterbitkan). Program Studi Pendidikan Bahasa dan Sastra Indoneisia, Universitas Negeri Semarang.

Ismayanti, Made Novi. 2017. Penggunaan Media Shadow Puppet untuk Meningkatkan Keterampilan Bercerita Siswa Kelas VII B SMP Negeri 2 Seririt. Skripsi (tidak diterbitkan). Jurusan Pendidikan Bahasa dan Sastra Indonesia, Universitas Pendidikan Ganesha.
Jalinus, Nizwardi dan Ambiyar. 2016. Sumber dan Media Pembelajaran. Jakarta: Kencana.

Januria, Ni Made. 2014. Meningkatkan Keterampilan Berbicara (Bercerita) Melalui Penerapan Teknik Menyelesaikan Cerita Siswa Kelas VII J SMP Negeri 2 Ubud Gianyar. Skripsi (tidak diterbitkan). Jurusan Pendidikan Bahasa dan Satra Indonesia, Universitas Pendidikan Ganesha.

Kustiawan, Usep. 2016. Pengembangan Media Pembelajaran Anak Usia Dini.Malang: Gunung Samudra.

Nasanti, Kinan. 2012. Menulis Cerita untuk Anak-Anak. Jakarta: PT Balai Pustaka.

Prastowo, Andi. 2014. Pengembangan Bahan Ajar Tematik: Tinjauan Teoretis dan Praktik. Jakarta: Kencana.

Simanjuntak, A.L. 2008. Seni Bercerita. Jakarta: PT BPK Gunung Mulia.

Suandi, I Nengah. 2014. Sosiolinguistik. Yogyakarta: Graha Ilmu.

Tedjasaputra, Mayke S. 2001. Bermain, Mainan dan Permainan. Jakarta: Grasindo.

Wati, Ega Rima. 2016. Ragam Media Pembelajaran. Yogyakarta: Kata Pena.

Wendra, I Wayan. 2013. Buku Ajar Keterampilan Berbicara. Singaraja: Universitas Pendidikan Ganesha.

Yani, Ahmad. 2014. Mindset Kurikulum 2013. Bandung: Alfabeta. 